\title{
Analysis of a Business Intelligence process based on Lean Office principles
}

Fabiane Letícia Lizarelli ${ }^{1}$, Federal University of São Carlos, São Carlos, São Paulo, Brazil

Luiza Franco Tonissi² ${ }^{2}$ Federal University of São Carlos, São Carlos, São Paulo, Brazil

José Carlos de Toledo ${ }^{3}$, Federal University of São Carlos, São Carlos, São Paulo, Brazil

\section{RESUMO}

Objetivo - Business Intelligence (BI) é a capacidade da empresa, por meio de tecnologias e métodos, transformar dados dos ambientes externo e interno em informações para melhorar o desempenho. A captura, gestão e transformação de dados podem ser entendidas como processos e apresentam necessidades de melhoria, que pode ser desenvolvido por meio de princípios e ferramentas Lean. Há um gap de conhecimento sobre aplicação de Lean Office em processos de BI. O objetivo é identificar desperdícios no processo de BI de uma empresa de serviços e propor melhorias por meio de ferramentas do Lean Office.

Metodologia - A pesquisa foi desenvolvida por meio de estudo de caso. Foram utilizados três instrumentos de coleta de dados: observação participante, análise documental e entrevistas documentadas. As análises foram conduzidas com base nos dados coletados e foram aplicadas ferramentas identificadas na literatura que auxiliaram na condução da análise do processo de transformação da informação.

Resultados - O artigo traz dois resultados principais, o detalhamento de atividades de um processo de BI, que são pouco exploradas na literatura, e um caso que evidencia a contribuição positiva da aplicação dos princípios e ferramentas do Lean Office para melhoria do desempenho de um processo de BI.

Originalidade/valor - Contribui para a melhor compreensão e criação de uma visão comum sobre o processo de BI entre pesquisadores e praticantes, e com um caso que discute o potencial do Lean Office para identificar desperdícios, analisar causas e melhorar o desempenho desse processo.

Palavras-chave: Business intelligence. Business analytics. Melhoria de processos. Lean Office.

\section{ABSTRACT}

Purpose - Business Intelligence (BI) is the company's ability, through the use of technologies and methods, to transform data from external and internal environments into information to improve performance. Capture, management and transformation can be understood as processes and these can present problems and need for improvement. This article presents a case of applying Lean Office in a BI process in a service large company. The goal is to identify BI process-related waste and propose improvements through Lean Office tools and principles.

Methodology - The research was developed through a case study. Three data collection instruments were used: participant observation, document analysis and documented interviews. The analyzes were conducted based on the data collected and tools identified in the literature were applied that helped in conducting the analysis of the information transformation process.

Findings - The article presented two main results, the detailed presentation of BI activities that are little explored in the literature, especially in developing countries, and the contribution of Lean Office's philosophy and tools for improving the management of a BI process.

Originality/value - It contributes to a better understanding and creation of a common vision about the BI process between researchers and practitioners, and with a case that exemplifies the potential of the Lean Office to identify waste, analyze causes and improve the performance of this process.

Keywords - Business intelligence. Business analytics. Process improvement. Lean Office.

1.Universidade Federal de São Carlos, Departamento de Engenharia de Produção, Caixa Postal 676, São Carlos-SP, CEP 13565-905, fabianelizarelli@gmail.com; https://orcid.org/0000-0002-8959-9982; 2. luiza.tonissi@ hotmail.com; https://orcid.org/0000-0002-7625-0984; 3. toledo@ufscar.br; https://orcid.org/0000-0001-9538-0584.

LIZARELLI, F.L.; TOLEDO, J.C.; TONISSI, L.F. Analysis of a Business Intelligence process based on Lean Office principles GEPROS.

Gestão da Produção, Operações e Sistemas, v.16, nº 14, p. 72 - 108, 2021.

DOI: http://dx.doi.org/10.15675/gepros.v16i1.2545 


\section{INTRODUCTION}

In a scenario of changes and a large flow of information, the ability to handle large volumes of data from different sources and transform them into intelligence has ceased to be an option and has become critical for organizations, contributing significantly to creating competitive advantage (SCHICK et al., 2011; TORRES et al., 2018). Business Intelligence (BI) is related to the organization's ability to collect, understand, analyze and transform its most valuable asset, that is, data, into information that contributes to good performance (AZVINE et al., 2005).

BI can be defined as the set of methods, technologies and products that make it possible for managers to use raw data and transform it into information that contributes to improving the organization's profit and performance (WILLIAMS; WILLIAMS, 2007). The purpose of BI is not only to transform data into information and information into knowledge, it also includes the communication of this knowledge, clearly and through graphics and dashboards for employees, customers, suppliers and other stakeholders (BOLOGA; BOLOGA, 2011; CHEN; CHIANG; STOREY, 2012).

Through the application of data analysis techniques, BI creates conditions for the organization to become dynamic, supporting strategic decision making and the business strategy itself (OLSZAK; ZIEMBA, 2003; THOMPSON; VAN DER WALT, 2010). Due to the strategic impact it can cause, as well as improved performance, BI has received increasing interest from companies and researchers (RICHARDS et al., 2019).

Information Technology (IT) initiatives, such as BI, represent strategic importance not only in companies in developed countries (GONZALES; WAREHAM; SERIDA, 2015). For organizations located in developing countries, BI can also play an important role in competitive advantage (GONZALES; WAREHAM; SERIDA, 2015) and technology, in this context, can be an opportunity for organizations to improve and streamline their business processes, evolving more quickly (STEINMUELLER, 2001).

$\mathrm{BI}$ processes, as well as other processes performed in offices, have waste that occurs in tasks that generate cost and consume resources without adding value to the customer (GANESAN; GOPALSAMY, 2019; RENO, 2016). Research shows the main reasons for failures in BI projects indicating waste of time in the creation and maintenance of dashboards, difficulties in obtaining real-time and reliable data, and delays in reporting for administration 
with the requested information (GANESAN; GOPALSAMY, 2019). Therefore, BI is a process that can benefit from improvement principles and tools.

The Lean Office seeks to apply the Toyota Production System mentality, principles and tools to the administrative environment (MCMANUS, 2005), the main focus is on systematically identifying and eliminating waste. In the case of administrative processes, such as BI, the value flow is related to the flow of information and knowledge, and these flows also aim to reduce waste (GANESAN; GOPALSAMY, 2019). This type of process presents difficulties in identifying the value flow, however, when optimized, it allows organizational improvement (MCMANUS, 2005). For that, Lean tools can be used, which help in the identification of the value flow, of the problems related to and in the proposition of improvements.

Lean concepts are not restricted to manufacturing, they can also be applied to management and service environments, covering different types of organization (GUPTA; SHARMA, 2018). Although widely used in manufacturing, Lean practices are still relatively new in services, with few documented approaches (LEITE; VIEIRA, 2015).

The digital transformation is gaining increasing interest from service and manufacturing companies, this transformation encompasses the use of large volumes of data, data analysis and business analysis through these data (FREITAG; SANTOS; REIS, 2018). However, there are few studies in the literature that deal with the joint application of Lean Office and digital transformation (FREITAG; SANTOS; RE IS, 2018). There are few studies that directly highlight the connection and potential benefits between approaches such as Lean and the analysis of big data, through theoretical or empirical research (ANTONY et al., 2018).

The adoption of Lean in certain sectors, such as IT and financial services, has been seen as important factor for competitiveness, as these sectors are exposed to global competition and serve customers from all over the world and need to remain in the market (GUPTA; SHARMA, 2018).

Another point is that in developing economies, such as in Brazil, Lean initiatives in service processes are important, as they allow organizations with limited resources to make improvements in the process and in the work environment and enable employee education and training, making the companies more competitive (GUPTA; SHARMA, 2018). However, the rates of change and implementation of Lean have been slow in developing economies, mainly 
due to the lack of training on Lean practices and limited resources for the execution of improvement projects (GUPTA; SHARMA, 2018).

A first gap in the literature, which the present research seeks to fill, consists of the lack of practical evidence of a specific case of Lean Office application in processes involving a big data and BI, which will make it possible to discuss the effectiveness of its principles and tools for this application. A second gap deals with the absence of cases in developing economies, an important scenario both for applying Lean principles and tools and for the BI process.

An evidence of the gap in the application of Lean in the BI process was a systematic review of the Web of Science and Scopus databases with the terms (( "Business Intelligence" OR "Business Analytics") AND ("Lean")), despite the return of some papers (16 and 34 respectively), without a date filter, after reading the title and abstract, it was found that no journal paper effectively addressed the topic of application of the Lean Office in a BI process.

Considering the importance of BI, the increase in the volume of available data and the appropriate treatment of these and understanding that BI processes are susceptible to waste in the information flow, the objective of this research is to identify waste related to the BI process and propose improvements through Lean Office tools. Upon reaching this objective, through a case study, it is expected to verify that the Lean Office and its tools can identify waste in this type of process and improve it, considering a context of developing economy. Therefore, the research seeks to fill the two gaps of knowledge mentioned above. The company already has BI processes and tools in place, which justifies the choice for conducting the field research.

The article is organized as follows: Section 2 deals with the theoretical background on BI, BI process and Lean Office and its tools, Section 3 presents the research method, Section 4 the Case Study, Section 5 the Discussion and Section 6 the Conclusions.

\section{THEORETICAL FOUNDATION}

\subsection{Business Intelligence}

An organization's wealth is less and less related to material and financial assets, and more and more to intangibles (OLSZAK, 2016). The economic and technological scenario has changed the reality of competition between organizations. High levels of technology started to be employed, generating rapid changes in the business environment. The ability to capture 
and process information in an agile and effective way has become not only a differentiating factor, but a critical aspect for survival (LÖNNQVIST; PIRTTIMÄKI, 2006; PETRINI et al., 2004). These are added to the challenge of maintaining such ability in an ever-changing environment and with an increasing volume of information (OLSZAK, 2016).

BI can be understood as the reduction of large volumes of data in knowledge, through a process that involves the filtering, analysis and dissemination of information providing the meaning behind data (THOMPSON; VAN DER WALT, 2010). When data acquire meaning, they are transformed into information, which through analysis is transformed into knowledge by experience in intelligence (VUORI, 2006; CHEN; CHIANG; STOR EY, 2012). The past few years have witnessed the development of big data and BI systems to measure and support decision making, among other purposes (GOTI et al., 2018).

The central theme of $\mathrm{BI}$ is to use massive data to help organizations obtain competitive advantages (WANG; WANG, 2008). BI can be understood as a comprehensive term for several business management processes, which encompasses strategies, technologies and information systems used by companies to extract large volumes of relevant data and knowledge to support a wide range of operational, tactical and strategic decisions (MUNTEAN, 2018). BI aims to generate accessible and shareable information so that employees are able to do their work effectively, making decisions based on data (GANGADHARAN; SWAMI, 2004). From a strategic point of view, BI supports performance planning and measurement (RICHARDS et al., 2019).

BI can be seen as a product and a process. The product with regard to the set of information on the present and future behavior of the market, of competitors, suppliers, customers, trends, acquisitions and technologies. As a process, BI consists of a set of methods, which the company uses to explore and use information for the sake of good competitive performance (GOTI et al., 2018).

\subsection{BI Process}

Regardless of the size of the company, information is considered a competitive advantage and in current organizations, the volume of data available is increasingly larger, requiring, for its analysis, advanced Business Analytics functions (RICHARDS et al., 2019). Several data are generated even considering only the company's internal operations and indicators (MUNTEAN, 2018). A simple transaction can provide information about the 
date of sale, price, discount, customer name, address, gender, age, etc. The organization must convert this huge volume of data into valuable information for decision-makers, helping to improve performance (SAED, 2013).

BI is composed of administrative and technical elements. The first approach emphasizes the process of collecting data from internal and external sources of the company and its analysis, in order to generate information for the decision-making process; while the technical approach focuses on the technological tools that support the process (OLKSAK, 2016). The business models generated by BI, from a technical point of view, are not viable without the support of information technology systems (MUNTEAN, 2018). The technical approach emphasizes the BI tools used, the focus is less on the data transformation process and more on the technologies that make it possible to record, retrieve, manipulate and analyze information after the data has been collected in heterogeneous sources and distinct formats (OLSZAK, 2016; PETRINI et al., 2004; POLYVYANYY et al., 2017).

Typical BI process steps include modeling business rules, create data profile, data warehousing and analytical processing and data mining (WANG; WANG, 2008). BI structures allow the processing and generation of complex analytical reports, currently they are identified as business analysis structures (Business Analytics) (MUNTEAN, 2018).

The intelligence process of a company begins with the capture of raw data from different sources, which portray the daily and operational transactions of the company that can serve different purposes (RICHARDS et al., 2019). In a second stage, the data is filtered and aggregated, resulting in information when acquiring a contextual meaning, which allows interpretation and understanding. New technologies reduce the complexity of this stage (MUNTEAN, 2018). Finally, intelligence takes information to a higher stage, uniting the interpretation and understanding of information to direct decisions in certain contexts (PETRINI et al., 2004; MUNTEAN, 2018).

The BI process begins with the step of accessing and integrating data (structured data relating to reports and reports from the company itself or unstructured, usually collected from external sources such as the internet, third parties, etc.) from different sources and stored in data warehouses (DW) (BOLOGA; BOLOGA, 2011; MUNTEAN, 2018; POLYVYANYY et al., 2017). The second stage is the transformation of information into knowledge through data analysis tools and information management systems (BOLOGA; BOLOGA, 2011). The 
third stage deals with the transformation of information into knowledge through dissemination tools such as easy-to-understand graphical interfaces, and the last stage would be decision-making itself (BOLOGA; BOLOGA, 2011; RICHARDS et al. 2019).

Unstructured data, after being collected proactively, is filtered, organized and stored, being internally accessible by the company, through its information management system (BOLOGA; BOLOGA, 2011). Structured data is constantly collected by processes such as transactions, logistics operations and revenues. These data are first stored in operational databases and undergo the process of extraction, transformation and storage, becoming information stored in DW (RICHARDS et al., 2019). Analysis tools are used to understand the set of information and to acquire knowledge from it. Finally, report generation tools are used to make the analysis more understandable, through graphs and interactive dashboards (BOLOGA; BOLOGA, 2011; RICHARDS et al. 2019).

The BI process is closely related to the decision-making process (RICHARDS et al., 2019). It consists of the steps of defining the necessary information, collecting information, processing information, analysis, dissemination and use and feedback (SKYRIUS et al., 2013; RICHARDS et al., 2019). The BI process has a cyclical character, since through feedback after the use of information, it is possible to return to the initial stage and redefine and reassess the need for information. Internal changes to the organization, the perception that the object of study was incorrectly evaluated, for example, by omitting important information or by including other irrelevant ones, may be reasons for feedback to invoke the reassessment of the need for information (SKYRIUS et al., 2013).

Considering the BI stages, in the case of an analysis signaling any alert, whether due to problems or opportunities identified, the decision-making cycle begins, with deeper analysis and better understanding of the aspects related to the issue. After the data becomes information that supports decisions, the knowledge and perceptions acquired in this experience are accumulated, enriching the company's intelligence and improving both processes for future applications (SKYRIUS et al., 2013). The integrated BI and decisionmaking steps are shown in Figure 1. 
Figure 1 - Relationship between Business Intelligence cycles (1) and decision support (2)

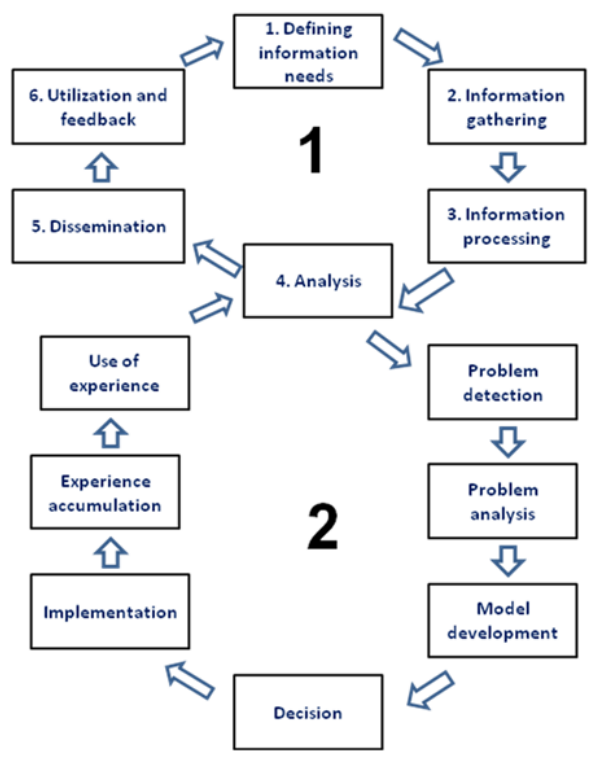

Fonte: Skyrius et al. (2013)

\subsection{Implementation of the BI process}

The implementation of quality BI processes can bring numerous benefits. However, to take advantage of BI activities that result in intelligence and support decisions, it is necessary for the organization to undergo a transformation that involves everything from technical and technological aspects to cultural characteristics (MAVI; STANDING, 2018).

One of the main factors for the implementation of BI is the availability of IT resources by senior management, creating conditions for the storage, processing and availability of large volumes of information, in an integrated way for the entire organization and provision of data analysis and visualization tools (DAVENPORT, 2006; OSZACK, 2016; W IXOM; WATSON, 2001). Another important factor is the creation of an integrated and nonfragmented BI for the entire organization (DAVENPORT, 2006). This includes avoiding tools, DW, and fragmented training across areas, generating multiple bases, with inconsistent formats, definitions and misleading data and many conflicting indicators and information. It is necessary that a group is dedicated to ensuring that data is well managed and that the organization's stakeholders are able to access and share information (DAVENPORT, 2006). 
Understanding when using information for decision-making can be impaired, for example, by the quality of information, information integrity, the performance of managers with little experience, the absence of standardized practices for monitoring the company's performance, among others (POPOVIC et al., 2012). Human factors for BI adoption are just as, or more important than technological factors, since all BI activities are performed by humans. The technology just accumulates and translates the will of the operators, it is necessary that aspects of the strategy are implicit in the input provided by man to the BI system or in the reading and interpretation of the outputs generated by this system (SKYRIUS et al., 2013).

A corporate culture open to $\mathrm{BI}$ implementation is needed, where the BI culture is part of the organization's culture, effective management is also necessary, with a known and supported information transformation process, with a team that adds different knowledge and experiences, strategies, and objectives clearly defined and appropriate use of technologies (OSZACK, 2016).

BI has become vital for many organizations due to its ability to gather a vast amount of data, from multiple sources and systems, and return, as an output, visions focused on the business (GANGADHARAN; SWAMI, 2004). It has become a necessity for companies, as a basic tool for modern administration (BOLOGA; BOLOG A, 2011) for all types of businesses and sizes of companies (GANGADHARAN; SWAMI, 2004).

\subsection{Lean Office}

The Lean Office emerged from Lean Production and is an approach that aims to eliminate waste throughout administrative processes (MAGALHÃES et al., 2019). The concept of Lean Thinking, although very associated with manufacturing, has migrated to application in processes or service organizations (DANESE et al., 2018; HINES et al., 2004; MONTEIRO et al., 2015). The Lean Thinking can be defined by a form to specify value, define and improve the sequence of activities that create value, perform these activities without interruption so increasingly effective. It is a daily and continuous process within the organization and cannot be seen as a program that has a beginning and an end (LOCHER, 2011).

The five principles of Lean, which guide the actions for having a Lean Thinking are value (specify the value, defined by the customer and created by the company), value flow 
(observe the process of creation until consumption, identifying activities that add value, those that do not add value to the customer, but are necessary, and activities that do not add value and are not necessary, and should be eliminated), continuous flow (giving the process fluidity, trying to make it as continuous as possible), pulled production (only what is required by the next process, reducing stock levels), perfection (ensuring that everyone involved in the value flow engaged in the search for the perfection of processes) (HICKS, 2007).

The application of Lean principles in administrative areas is called Lean Office and aims to eliminate waste arising from this type of process (CAVAGLIERI; JULIANI, 2016). According to Tapping and Shuker (2010), $60 \%$ to $80 \%$ of the costs involved in meeting a client's demand are of an administrative nature. Therefore, the reduction of waste can generate significant gains for companies, reducing the high administrative costs (CAVAGLIERI; JULIANI, 2016).

The Lean Office arises from the application of Lean mentality and principles to the environment administrative (Almeida et al, 2017; CHEN; COX, 2012). In this case, the value flow is related to the flow of information and knowledge, and it is in these flows that the aim is to reduce waste. One of the difficulties encountered when applying the Lean mentality to the service environment is to identify the flow of value, given that the information is abstract, unlike physical products that move (ALMEIDA et al., 2017 ; FREITAS et al., 2018). Principles such as the elimination of waste, standardization of processes, flow of value and customer voice and respect for humanity remain valid for the service environment (GUPTA; SHARMA, 2018). The flow of value in these environments is given by information and knowledge different from the materials and components of production (HINES et al., 2004). The continuous flow must be obtained by planned and efficient interactions, the pulled production is guided by the needs of the company and not by the takt time, and the perfection obtained through processes that allow for improvement and not just without errors.

Service processes also suffer from inefficiency and the main reasons include the lack of standardization, inconsistency and rework that reduces performance, in addition to the inability to analyze and manage the factors that drive workforce productivity and customer satisfaction (GUPTA; SHARMA, 2018). The application of Lean in services can lead to improved competitiveness and customer satisfaction and reduced variability and waste of processes (GUPTA; SHARMA, 2018). In the administrative environment, efficient 
information management can promote advantages and create significant financial benefits (MAGALHÃES et al., 2019).

The waste that occurs in the office is tasks that generate cost and consume resources without adding value to the client (ALMEIDA et al., 2017; RENO, 2016). The main waste in services can be classified as (MALLADI; DOMINIC; KAMIL, 2011; GUPTA; SHARMA, 2018): inventory (number of requests, analyzes awaiting processing); delays in services and activities; defects (deliveries in disagreement with requests); movement of employees within the work environment; unnecessary transport of items and documents; overprocessing; excess production and generation of information and human effort for actions that do not add value.

According to Reno (2016), this waste can be classified into three groups: border waste; waste of knowledge; and planning waste.

The first group consists of losses of knowledge inherent in information transfers: searching for useless information; waiting for information and redundant tasks. The waste of knowledge is related to creative activities, which can be problems of reinventing knowledge; or quality issues, such as rework or poor-quality information. The group of planning wastes occurs due to the lack of a systemic view of the business and processes, in addition to the lack of interaction between the parties (RENO, 2016; SERAPHIM et al., 2010).

These wastes can be eliminated with the help of lean tools, some of which are described in the following section. According to Tapping and Shuker (2010), the steps for implementing Lean in administrative environments involve the use of practices and tools such as: commit to Lean; choice of value stream; learn about Lean; map the current state; identify lean metrics; map the future state; create Kaizen plans; and implement Kaizen plans. The Lean can be applied in any environment where there is waste and opportunity to improve and requires discipline and commitment to principles and will put optics.

\subsection{Lean Office tools}

\section{Poka-Yoke}

The poka-yoke aims to obtain zero defects and eliminate quality inspections, through the identification of errors (VIDOR; SAURIN, 2011). One of the ways that the pokayoke system is able to avoid failures is by blocking processing or warning the occurrence of 
the abnormality as soon as it is detected. This technique can be used, in addition to manufacturing processes, in documents and databases to ensure that information is recorded in specific field, in a standardized and easy to understand manner (MONTEIRO et al., 2017; SAURIN et al., 2012).

\section{Value Stream Map (VSM)}

In the literature, recent studies on the implementation of the Lean Office highlight the use of the VSM tool to identify and eliminate waste and processes and, consequently, obtain performance and agility gains (FREITAS et al., 2018). The VSM makes it possible, in a simple way, to give visibility to the process and facilitate decision making (ROTHER; SHOOK, 1999). In administrative sectors, the VSM allows the visualization of the flow of activities and information necessary for a set of processes related to a theme (TAPPING; SHUKER, 2010). The VSM allows the understanding of the sequence of tasks and the rules of the process, in addition to promoting the retention of knowledge to the extent that all items of information inherent to the value flow are analyzed and recorded (FREITAS et al., 2018). It exposes past and future situations in accordance with the objectives outlined. After drawing the current flow map, highlighting the waste, the future state map is drawn, with the proposed improvements based on the observation of the current map (ROTHER; SHOOK, 1999; SALUNKE; HEBBAR, 2015; TORTORELLA et al., 2016).

\section{A3 report}

The A3 report is a tool with potential for problem solving (SOBEK; JIMMERSON, 2016) and used for the development of strategies and the presentation of solutions to daily problems. It is a tool that facilitates continuous improvement and presents steps on how kaizens should be implemented, and in offices it helps in learning from problem solving. Some of the differentials of this tool are the ease and accessibility, the succinct way of dealing with the problem, from its analysis to the generation of solutions, planning of implementation and monitoring, in just a report of the size of two A4 sheets (KOENIGSAECKER, 2011; SOBEK; JIMMERSON, 2016).

According to Sobek and Jimmerson (2016) there may be adaptations in the report model, depending on the application. The tool helps people to filter and refine the analysis, 
reporting only the essential information, so that it can be understood by other people, in addition to standardizing and visualizing how to deal with problems in the company.

Other important tools for the Lean Office include kaizen, 5S, FMEA, PDCA events, standardized work and performance indicators. Kaizen events guide the implementation of a culture of continuous improvement, in accordance with the principle of perfect Lean Thinking, promoting a cycle of incremental improvement in the routines of processes and standardization of procedures (FREITAS et al., 2018). Quality management tools are also implemented, such as 5S (the five senses - Seiri, Seiton, Seiso, Seiketsu and Shitsuke meaning: Use, Organization, Cleaning, Hygiene and Discipline), the PDCA cycle (Plan, Do, Check, Act), FMEA (Failure Mode and Effect Analysis) and visual management tools, which contribute to improving communication and information dissemination (FREITAS et al., 2018). Standardized work is a method to establish a set of standardized work procedures that are documented and describe the best way for workers to perform their tasks and can be used as a Lean tool for the administrative environment (MAGALHÃES et al., 2019). To achieve the goals, it is necessary to measure the results, for this situation the KPIs (Key Performance Indicators) are tools to measure the performance and help in the best decision making.

\section{METHODOLOGICAL PROCEDURES}

This is a descriptive research, whose objective is to portray characteristics of events and assist in the understanding of reality, in this case a BI process and its problems. To achieve the research objective, a qualitative approach was used. An important characteristic of qualitative research is that its focus is not on the product, but on the process, that is, on the understanding and description of the phenomena.

According to Yin (2001), the case study is appropriate in situations that portray contemporary events over which there is no control over behavioral events. The case study ensured that the research objective was reached and that the characteristics and problems of information flow were properly understood the analyzed and reported the in depth.

To understand how the BI process occurs, for the specific case, three different data collection instruments were used: participant observation, document analysis and documented interviews. The participant observation took place over six months of the analyzed process, 
with monitoring of the tasks performed by people from three organizational areas - Business Intelligence (BI), Business Analytics (BA) and Strategic Planning (SP). The document analysis was done in the company's databases that cover the studied flow, allowing a better understanding of the processes carried out in the data and information and of the problems addressed in the analysis. Interviews were carried out with three company employees who participate in the analyzed process and who directly perform tasks of the studied flow, in order to answer the questions of the semi-structured interview script presented in Table 1.

Table 1 - Research protocol

\begin{tabular}{|l|l|}
\hline Interview & $\begin{array}{l}\text { BI Analyst } \\
\text { BA Analyst } \\
\text { Strategic Planning Analyst }\end{array}$ \\
\hline Questions & $\begin{array}{l}\text { 1. What role does the area play in the organization? } \\
\text { 2. What are the tasks performed by the area in the analyzed process? } \\
\text { 3. What are the processes of information processing performed in the area? } \\
\text { 4. What are the activities that have an interface with other areas? } \\
\text { 5. What activities can be done otherwise? } \\
\text { 6. What problems does the area face in relation to these activities? } \\
\text { 7. What could be different/better? }\end{array}$ \\
\hline $\begin{array}{l}\text { Number } \\
\text { interviews }\end{array}$ & $\begin{array}{l}\text { As the case involved the definition of activities, three rounds of interviews were } \\
\text { conducted with each interviewee. }\end{array}$ \\
\hline Duration & Each interview lasted approximately 90 minutes. \\
\hline $\begin{array}{l}\text { Validation } \\
\text { meetings }\end{array}$ & $\begin{array}{l}\text { Three validation meetings were held of approximately } 45 \text { minutes each, with the } \\
\text { participation of interviewees and area managers. }\end{array}$ \\
\hline
\end{tabular}

Source: Prepared by the authors (2019).

Meetings were also held with the interviewees and with the managers of each area and to validate the proposed flows and improvements. The three interviewees were open during the interviews, willing to assist in understanding the process and the activities and problems related to the process. One of the researchers was responsible for synthesizing the information in the current and future VSM, as well as, preparing the A3 reports with the assistance and approval of the interviewees and managers of the area. The data collection period lasted six months $(07 / 2019$ to $12 / 2019)$.

Subsequently, analyzes were performed based on the data collected in the previous stage. Lean Office tools identified in the literature review stage were applied and which helped to conduct the analysis of the information transformation process. The analysis was based on the use of the VSM, Poka-Yoke, A3, 5W2H and 5 Whys tools.

In a first step, the current process was represented in a general way in a flowchart and in more detail through an VSM. In the second stage, the problems of the current flow were 
identified, and, in the third stage, a new value flow map was proposed with improvements raised with the aid of Lean Office tools. These steps were conducted by a researcher with the participation of respondents and managers from the three areas: BI, BA and SP. In the fourth stage, the case was reported and reviewed by the professionals involved (interviewed) and by the managers of each area, as a way of final validation of the future state of the process and of the proposals for improvement. The authors analyzed the results considering the main waste, principles and tools of the Lean Office. The research steps can be identified in Figure 2.

Figure 2 - Research steps

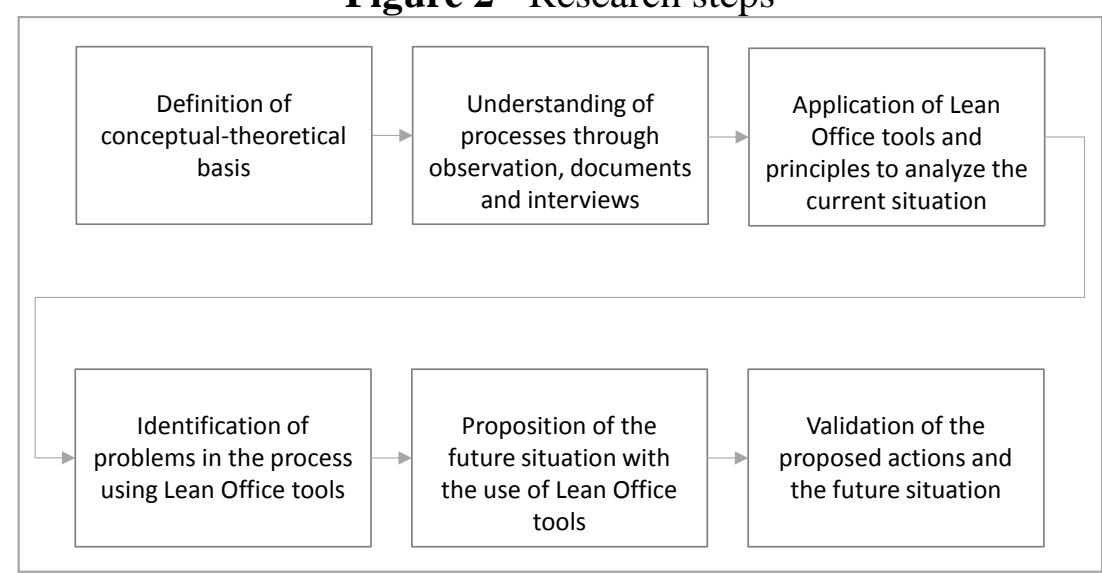

Source: Elaborated by the authors (2019).

\section{CASE STUDY}

The company studied is a Brazilian Financial Services. The operating segment is constantly changing, which includes the growth of startups that can compete with the service offered by the organization, and the rapid technological advances. The company has focused on innovation and the digital revolution, expanding the range of solutions and offering customers products resulting from data intelligence. Such a change in mentality has an impact on the company in a comprehensive manner, in all areas and processes. These changes of run of the need to adapt in order to be able to handle large volumes of data in an agile manner, with quality, to support decision making and to remain competitive.

The capture and transformation of data into information in the company is a practice that has resulted in investments in software for analyzing large volumes of data, such as SAS and Tableau, for storing raw data, and for manipulating primary databases. Such data is used 
both for the creation of products offered to customers and for internal use of the company, in performance analysis, product segmentation and strategic allocation of the sales force.

There are many possibilities for applying data intelligence in the company, involving the early identification of operational problems, the acquisition of new customers and the need for the customer to purchase products with a high profitability margin, even before the customer is aware of this need, increasing the product conversion rate.

The company already has IT infrastructure and processes for data analysis; however, it still faces difficulties related to the flow of transforming data into information. The following sections present the analysis of this transformation flow, from receiving raw data to generating knowledge for the company and customers.

\subsection{Analysis of the data transformation process}

The current flow of data transformation is represented in a simplified manner in Figure 3 and is composed of processes involving three areas of the company (Business Intelligence, Business Analytics and Strategic Planning). These processes are part of the flow of adding value to the raw data collected in the business operation until they become intelligence and result in improvement actions for the business itself or products for customers.

The study focused on three stages of the process (steps 2, 3 and 4 of Figure 3). The raw data collection process and the first steps of processing this data will not be considered, as they are activities that describe the use of software and its commands. The same happens with step 5 and, for this reason, it has not been explored either.

Figure 3 - Macro steps of the process and responsible areas. 


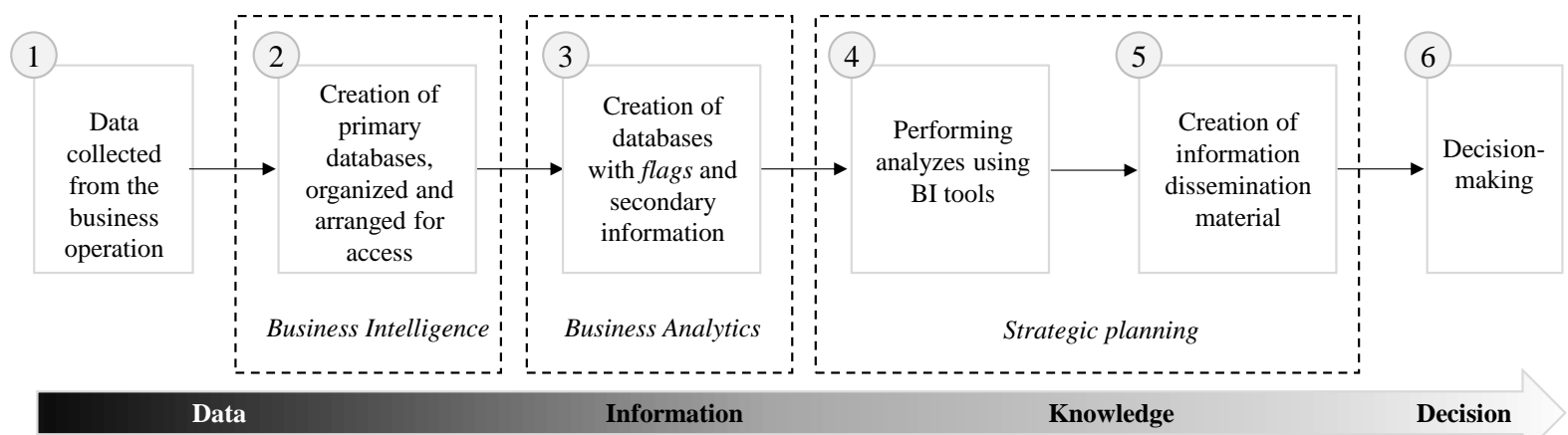

Source: Prepared by the authors (2019).

The areas involved in the analyzed process have specific functions and characteristics. Below, the characteristics and function performed are described for each of the areas: Business Intelligence, Business Analytics and Strategic Planning.

\section{Business Intelligence}

The BI area is composed of 10 people who work in order to standardize and organize information for other areas in the company. It is responsible for connecting other areas with the information captured by the Information Systems. This means that the area receives the operational data of the business, which are captured by different systems, and prepares them to be used by the other areas.

The area works transforming raw data into business information. With a frequency of five times a day, the area receives text files with data originating from two sources: Base 1 and Base 2. Base 1 reports to authorization information for financial transactions of customers processed in two different systems. Base 2 is related to more specific information, for example, the value of transactions.

After receiving the data from the two bases, the BI team acts in the ETL (Extract, Transform, Load) functions, that is, extracting the data from the received text files, transforming them into organized databases that meet the demands of other areas and, finally, loading and storing the information treated in the company's DW. The last process carried out by the area is to make the data available, in an organized manner, to the other areas. This means that, according to the needs of other areas, BI creates bases and folders organized by themes and that can be accessed via a specific platform in the internal system so that they are easily accessible.

\section{Business Analytics}


BA is made up of 15 people, including manager and coordinators, specialists and analysts. The main value of the area is to use statistical modeling and analysis tools to generate new indicators. BA's customers are both customers of the company, as other areas of the organization using the analysis, databases and indexes generated by them.

One of the processes carried out by BA involves building a general base (GB). On this base, primary customer information is available, that is, that obtained from the operation of the business and the registration systems, and contains secondary information generated by BA, based on the organization's primary information. This is done through statistical modeling, which generates new indicators and classifications, which are important for the analyzes carried out by the other areas of the company.

\section{Strategic Planning}

The SP consists of 15 people, including managers, coordinators and analysts. This area directs and supports decision-making, through analysis, proposal of actions and monitoring of the results of the implementations. It uses internal data, market, monitoring of competition and performance trends in the segment in which the company operates. Its clients are the president, vice presidents and other areas that request management support.

The SP acts in the information transformation process in two ways: performing analyzes (generating knowledge) and interpreting the results (generating intelligence). Coordinators and analysts have a fundamental role in interpreting the analyzes, adding to the indicators the knowledge they have due to experience.

\subsection{Current information flow description by VSM}

Table 2 presents the activities developed in steps 2, 3 and 4 of the flow in Figure 3, detailing what they are, the area responsible for execution, the waiting and processing times for each one and the Lead Time (Processing time + Total Waiting Time) of the process. Times were obtained from interviews with employees.

Table 2 - Activities of the current information flow. 


\begin{tabular}{|c|c|c|c|c|c|}
\hline Macro Steps & Activities & Detailing & Area & $\begin{array}{l}\text { Standby } \\
\text { time }(h)\end{array}$ & $\begin{array}{l}\text { Processing } \\
\text { time }(h)\end{array}$ \\
\hline \multirow{3}{*}{$\begin{array}{l}\text { Creation of an } \\
\text { organized and } \\
\text { willing billing } \\
\text { base for access }\end{array}$} & Extract Data & $\begin{array}{l}\text { Extract raw data from files received } \\
\text { by systems } 5 \text { times a day }\end{array}$ & $\mathrm{BI}$ & 0.0 & 1.0 \\
\hline & Transform data & $\begin{array}{c}\text { Raw data is processed } \\
\text { (standardization of nomenclatures, } \\
\text { data validation) }\end{array}$ & $\mathrm{BI}$ & 0.0 & 2.0 \\
\hline & Record to DW & $\begin{array}{l}\text { Store processed data and make it } \\
\text { available for access from other } \\
\text { areas }\end{array}$ & BI & 0.0 & 1.0 \\
\hline \multirow{4}{*}{$\begin{array}{l}\text { Creation } \\
\text { of "GB" with } \\
\text { markings and } \\
\text { secondary } \\
\text { information }\end{array}$} & Access data & $\begin{array}{l}\text { Data access by customer, product } \\
\text { and operation }\end{array}$ & $\mathrm{BA}$ & 48.0 & 0.5 \\
\hline & $\begin{array}{l}\text { Create metrics } \\
\text { and markups }\end{array}$ & $\begin{array}{l}\text { Use of tool (for example, SAS) to } \\
\text { join database with new data; } \\
\text { Updating registration information; } \\
\text { Creation of metrics (e.g., average } \\
\text { customer monthly volume) and } \\
\text { markings used by internal } \\
\text { customers }\end{array}$ & $\mathrm{BA}$ & 0.0 & 8.0 \\
\hline & $\begin{array}{l}\text { Validate and } \\
\text { store GB }\end{array}$ & $\begin{array}{l}\text { Checking information against } \\
\text { original company bases; } \\
\text { Verification of empty registration } \\
\text { information; Base storage in the } \\
\text { system }\end{array}$ & $\mathrm{BA}$ & 0.0 & 2.0 \\
\hline & $\begin{array}{l}\text { Communicating } \\
\text { Internal Clients }\end{array}$ & $\begin{array}{l}\text { Notify, by email, that the base is } \\
\text { ready for use (consumption) }\end{array}$ & $\mathrm{BA}$ & 0.0 & 0.2 \\
\hline \multirow[t]{3}{*}{$\begin{array}{l}\text { Generate analysis } \\
\text { and knowledge }\end{array}$} & Access GB & $\begin{array}{l}\text { Use of tools such as SAS to access } \\
\text { and filter information about } \\
\text { customers according to the need for } \\
\text { analysis }\end{array}$ & SE & 0.0 & 0.5 \\
\hline & Generate analysis & $\begin{array}{l}\text { Use of a tool to generate graphical } \\
\text { analysis and dashboards }\end{array}$ & SP & 0.0 & 6.0 \\
\hline & $\begin{array}{l}\text { Create } \\
\text { promotional } \\
\text { material }\end{array}$ & $\begin{array}{l}\text { If no errors are found, the material } \\
\text { can be made available to Senior } \\
\text { Management. If errors are } \\
\text { identified, it is necessary to wait for } \\
\text { corrections and reprocessing }\end{array}$ & SP & 0.0 & 3.0 \\
\hline \multicolumn{6}{|c|}{ Lead Time $=72 \mathrm{~h}$} \\
\hline
\end{tabular}

Source: Prepared by the authors (2019).

The current general information flow, with the activities and areas involved, is represented in the flowchart of Figure 3. Figure 4 shows the details of the activities in steps 2, 3 and 4, chosen for analysis. The VSM current status was made and validated with the help of the interviewees. From the analysis of the VSM of the current state, the interviews and the participant observation, it was possible to identify problems in the information flow that hinder the performance and quality of the process, also pointed out in Figure 4.

Four problems were identified in the flow: 1. The recurrent non-validation of metrics by $\mathrm{BA} ; 2$. Identification of inconsistencies in the database when generating the 
analysis; 3. Bases not easily traceable; 4. Failure to understand the base fields. In order to propose solutions to these issues and direct the construction of the VSM, three A3 reports were made (two problems had similar causes and actions for their mitigation) with the objective of finding the root cause of the problems and proposing solutions. 
Figure 4 - Current state and problems in the process

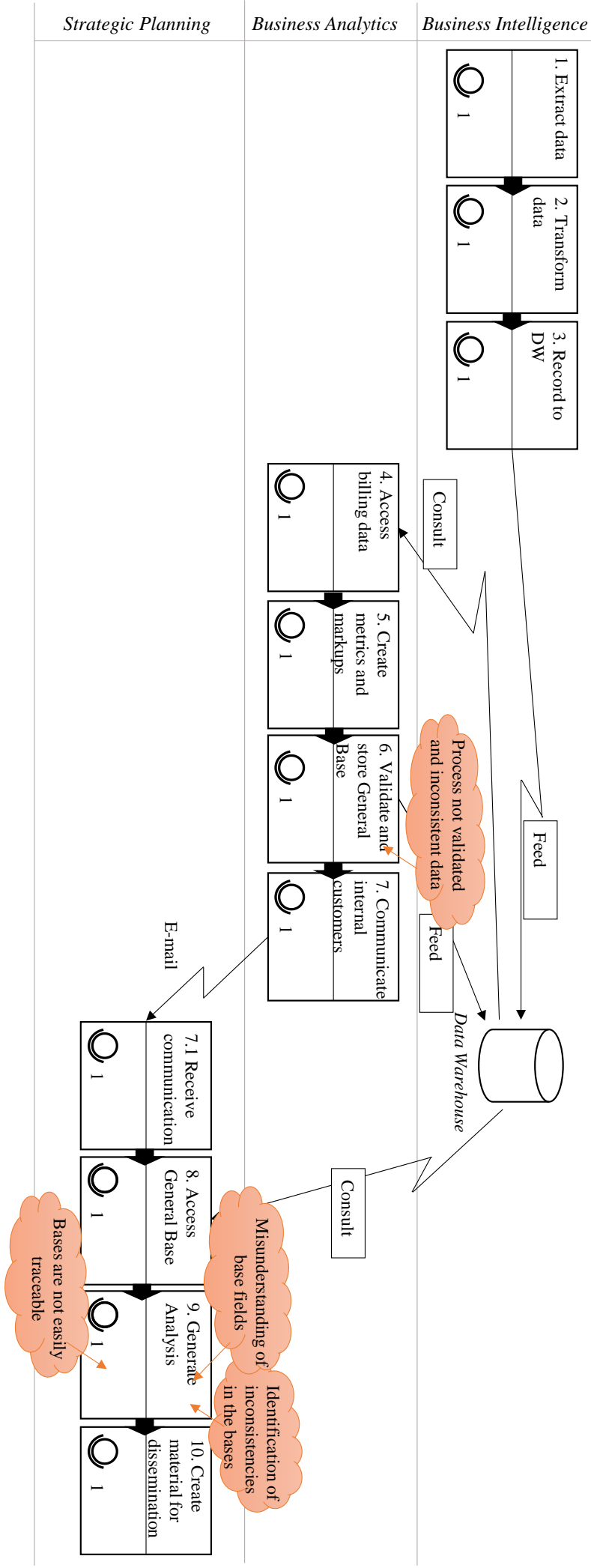

Source: Prepared by the authors (2019). 


\section{Process not validated by BA and inconsistency}

The processing and creation stage of GB metrics and markings takes place over a business day ( 8 hours) and validations are made the day after creation. According to the BA analyst's report, often in the validation process (Validate and store GB), GB's information does not match the company's original bases.

Considering that the information is not changed by BA during the creation of GB, and that both information (from the base and the comparison) originate from the same source, the difference between the two values can be attributed to the difference in date of access to the information. This would not happen if the monthly values were already ready by the time BA consulted the DW, that is, if all the information available in the company's information systems had already been received and stored in the DW by BI before the moment of the consultation.

As a routine, BA accesses the information related to the previous month on the second business day of the current month, assuming that until now the information for the previous month is already complete in the system and should not undergo further changes. However, it is clear that this has generated problems for the area, rework, reprocessing and delays in making GB information available for use by other areas.

Figure 5 shows the A3 built based on this issue, in order to find the root cause, propose countermeasures and an implementation plan. To define the root cause, the 5 Why tool was used and, in the implementation plan, the 5W2H was adapted, specifying what should be done, why to do it, how and who.

Although at first it was considered that the failure was due to the lack of recurrent validation by $\mathrm{BA}$, it was identified, through the construction of the A3, that it was necessary to include activities for the BI area as a solution to the root cause. During an interview with the BI employee in charge of the tasks analyzed, it was found that the client areas should be responsible for validating the information.

Following the principles of poka-yoke, it was proposed as a countermeasure to perform an automatic validation of information early in the process of transformation of date to alert the operator in the event of abnormalities identification. Under the responsibility of the BI, such validation must be applied in order to avoid the propagation of failures from the beginning of the chain and must be performed with the aid of automated programs that 
read the data and measure relevant aspects, indicating the occurrence of distortions in relation to expected (program input). Therefore, the new BI activities include validating information and communicating to customers that it can be used.

Figure 5 - A3: Analysis of the problem of lack of validation and inconsistency.

\section{Data validation and inconcistency problems}

\section{Context}

During the General Base validation process, the BA area finds inconsistency in the billing amounts processed the previous day

\section{Current condition}

- General Base always processed on the second business day, using information from the previous month;

- Process not validated which generates rework and delays due to having to generate a new base;

Root cause analysis

1. Why are there problems with the database? Because the monthly invoicing volumes generated in the General Base do not match the monthly volumes

2. Why don't the volumes match, even from the same source and from the previous month?

Because the validation occurs one day after extracting the DW to generate the General Base and there are changes

3. Why does the volume change from day to day? Because the volume is not completely stored in the DW at the moment BA extracts the base

4. Which BA extracts before the complete information? Because BA is not warned that information is incomplete when there is a delay (from Systems to BI)

5. Why is it not warned and the information is not ready? Because there is no procedure to communicate when it is ready

\section{Countermeasures}

Create procedures to communicate customer areas that the information is ready for consumption

\begin{tabular}{|c|c|c|c|}
\hline What & Why & How & Whom \\
\hline $\begin{array}{l}\text { Communicate } \\
\text { customer areas } \\
\text { when } \\
\text { information is } \\
\text { ready for } \\
\text { consumption }\end{array}$ & $\begin{array}{l}\text { Reduce } \\
\text { rework by } \\
\text { using } \\
\text { inaccurate } \\
\text { data } \\
\text { Reduce } \\
\text { chance of } \\
\text { wrong analysis } \\
\text { due }\end{array}$ & $\begin{array}{l}\text { Create e-mail } \\
\text { routines for } \\
\text { key } \\
\text { customers }\end{array}$ & $\mathrm{Bl}$ area \\
\hline
\end{tabular}

Key Indicators

General Base processing number due to volume inconsistency (quarterly)

Sending e-mail with information that the information is ready (once a month)

Source: Prepared by the authors (2019).

\section{Identification of inconsistencies in the bases}

The SP area analyst reported that the area uses GB to carry out specific analyzes, carried out on demand, and those scheduled on a monthly basis. When it comes to monthly analyzes, analysts already know the history of the information and are able to judge whether the results of the analyzes are consistent with reality and indicate when there are problems at the base. However, in several situations, it is not possible to guarantee that the critical sense of analysts is able to identify problems at the base.

Similar to the previous problem, the lack of validation of the database at the beginning of the process makes SP perceive inconsistencies only at the end of processing. This generates 
waste and rework by adding value to invalid data. Even BI validation fails to identify some types of problems, as validations verify that the data is in the appropriate formats and does not include the value of the information contained in the data. The solution found to eliminate the root cause was similar to that of the previous problem, proposing a poka-yoke as a countermeasure, which contemplates the execution of an automatic validation of the information at the beginning of the data transformation process, performed by the BI area. The A3 report can be viewed in Figure 6. With the proposed measures, insertion of the BI validation activity, it is expected that the incidence of processing invalid information for the generation of SP analyzes will be lower.

Figure 6 - A3: Analysis of the problem of inconsistency in the bases.

Inconsistency in the bases identified at the end of the information flow

\section{Context}

From the General Base, the analyzes are built by the Strategic Planning area. The results are evaluated by the analysts' sense and experience with data history.

\section{Current condition}

- Rework in the entire data processing chain, in case of identification of problems in the database;

- Number validations depend on the knowledge and experience of the analysts;

Root cause analysis

1. Why are problems found after the analysis, at the end of the process?

Because there is no correction in previous steps

2. Why are corrections not made in previous steps?

Because the validations of the areas responsible for previous processes do not identify certain types of problems in the information.

3. Why don't the previous areas identify? Because the validations made by $\mathrm{BA}$ and $\mathrm{BI}$ do not include all aspects, filters and important views for the end customers

4. Why can't the areas validate the information considering the main filters / views?

Because BI operates data validation processes and not information, BA validates information related only to the manipulations of the database

5. Why can't areas make more validations than they already do?

Because these procedures were not included in their routines and had no training

\section{Countermeasures}

$\mathrm{BI}$ perform the validation of the information considering important filters for the final customers, ensuring that any generated base would be right from the source; BA perform the validation of the information considering important filters for the final customers, guaranteeing the non-processing of invalid information;

\begin{tabular}{|c|c|c|c|}
\hline What & Why & How & Whom \\
\hline $\begin{array}{l}\text { Validate } \\
\text { information } \\
\text { considering } \\
\text { important } \\
\text { filters for end } \\
\text { customers }\end{array}$ & $\begin{array}{l}\text { Avoid } \\
\text { processing } \\
\text { information } \\
\text { without } \\
\text { validity Avoid } \\
\text { mistaken } \\
\text { analysis, due } \\
\text { to the failure } \\
\text { of the SP } \\
\text { analyst to } \\
\text { recognize } \\
\text { errors }\end{array}$ & $\begin{array}{l}\text { Create an } \\
\text { automated } \\
\text { system that } \\
\text { alerts the } \\
\text { operator } \\
\text { that there } \\
\text { are } \\
\text { variations of } \\
\text { more or less } \\
30 \% \text { of the } \\
\text { billing } \\
\text { volume } \\
\text { within the } \\
\text { main } \\
\text { classification } \\
\text { s used by SP }\end{array}$ & $\mathrm{BI}$ area \\
\hline
\end{tabular}

Key Indicators

Measurement (and reduction) of base problem identifications only at the end of the processing chain

Source: Prepared by the authors (2019). 


\section{Bases not easily trackable and fields not understood}

Two other problems raised were the difficulty of understanding some fields of the base and the difficulty of tracking the origins of the base. Often the base is made up of fields with similar information, but not the same and as there is no explanation of each field, the operator may not know which contains the correct information. Short, unintuitive names and very similar information between fields make it difficult to understand and manipulate this information.

To clear up doubts, the analyst can spend hours doing tests with that information, in order to determine which field is to be used. This leads to the second problem: the difficulty of identifying the origins of the base, as there is a lack of guidance on who generated the bases, or who knows how to answer questions. In this situation the BA or SP analyst may prefer to try to find the solution alone.

A3 (Figure 7) presents the analysis of these two problems in a unique way, finding a common root cause and proposing countermeasures.

As a solution, it was proposed to insert a new routine in BI activities. For each base created, the area should be in charge of filling out a standardized document that is available for easy access by any employee. In this document there should be information about which fields are contained in the database, the sources of information for each field, the formula or concept used in that field and the order of hierarchy between the fields. In addition, the base must include an indication of a responsible person, who must be familiar with it and who is available to answer questions from base users.

With this countermeasure, users of the database are expected to be able to resolve doubts quickly, with less chance of misinterpretation and better communication between the areas.

Figure 7 - A3: Analysis of the lack of information related to the origins of the bases. 


\section{Lack of information related to the origin of the bases}

\section{Context}

When using the bases to construct the analyzes, SP employees need to understand which metrics and concepts were considered for the construction of each "field" of the database. In case of doubts and problems, analysts need to contact those responsible for creating the information.

\section{Current condition}

- Analysts have doubts about the information in each field and spend hours checking other company information, in order to identify which concepts were used to create the database;

- The company uses more than one concept to build a "label" or definition;

- In case of doubts, it is not known who to speak to within the company;

Root cause analysis

1. Why does SP spend hours checking database information?

Because there are doubts about the concepts used and it is not known who built the base to clear doubts.

2. Why is it not known who built the base and its concepts?

Because the base is built upon request from some area, and often these are updated periodically, losing information about the origins of requests and constructions.

3. Why is the source information lost?

Because there is no procedure for storing this information at the time of creation.

4. Why are there no procedures to record the source information?

Because the areas at the beginning of the flow are unaware of the difficulties that the end areas have.

5. Why can't the areas at the end of the flow communicate with those at the beginning?

Because there is also no information on who to talk to.

Source: Prepared by the authors (2019).

\subsection{Proposal for a future information flow}

In this stage, a VSM of the future state of the information flow was constructed (Figure 8), considering the countermeasures proposed in A3.

As changes, four new activities were inserted in the flow. The changes were basically implemented in the BI processes. For this area, the tasks of building the standardized document were added, with detailed information from the fields and the author of the database, validating the information after the data transformation stage, and the task of communicating the client areas that the databases are ready for use.

For $\mathrm{BA}$, the task of receiving the $\mathrm{BI}$ report was added before consulting the DW to retrieve the data. 
Figure 8 - VSM of the future state of the information flow.

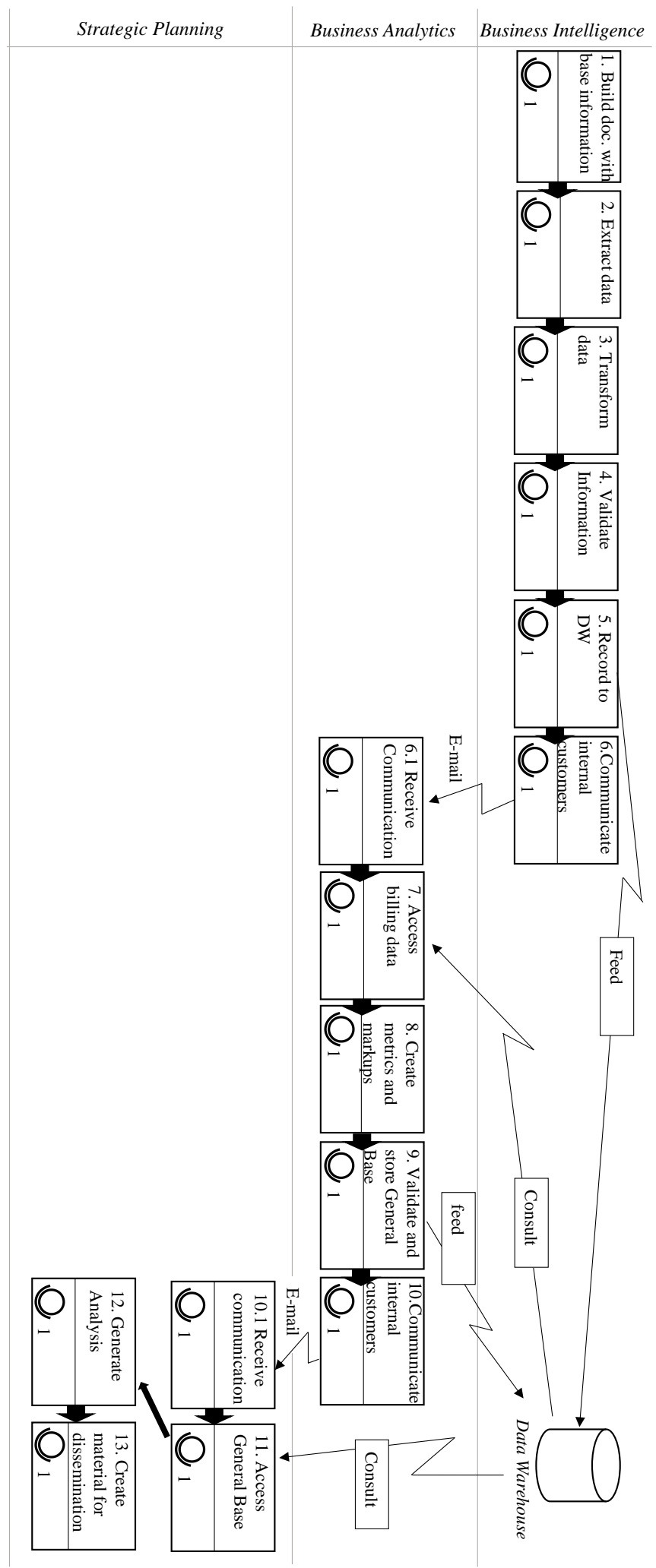

Source: Prepared by the authors (2019). 


\section{DISCUSSION}

The article presents two main contributions, in relation to the knowledge of the BI process and its analysis by the Lean Office for the identification and mitigation of waste.

\subsection{Analysis of the information flow process}

The intelligence process studied begins with the capture of raw data from different sources, which portray the company's daily and operational transactions and serve several purposes (RICHARDS et al., 2019). In a second stage, the data is filtered and aggregated, resulting in information acquiring contextual meaning. Finally, intelligence allows the interpretation and understanding of information to guide actions and decisions.

The traditional recommendations for investments in information technology, software suitable for data processing and developing an organizational culture of valuing information management and generating knowledge to support decisions (DAVENPORT, 2006; OSZACK, 2016; WIXOM; WATSON, 2001) are present in the company. However, there are still difficulties in integrating the functional areas involved in the business intelligence process, which are manifested in the fragmentation of process practices, failures in the common view and coordination of the macro process and in the quality of data and indicators generated by the process. These failures lead to wastes that are common in service processes (RENO, 2016; LEITE; VIEIRA, 2015) and to specific wastes from BI processes (GANESAN; GOPALSAMY, 2019). The organization's traditional structuring and management model, preexisting to the introduction of the BI process, may be influencing these failures. As an implementation process, its structuring and management must evolve in maturity as important conditioning factors, of the process itself and of the organization, are present or in consolidation (MAVI; STANDING, 2018).

The realization of the case study in the company, the analysis of the process and the discussion of the identified problems, in a participatory way, lead to a greater awareness and improvement of the process. In addition, the reflection on what is value in a BI process, necessary for the elaboration of the process mapping and the value flow, also contributes to this evolution. According to Ganesan and Gopalsamy (2019), the vision and consensus on what is value in service processes, and business intelligence, are relatively complex and the case report contributes through exemplification. According to Gupta and Sharma (2018), in 
developing countries there is a lack of even examples of the implementation of business intelligence processes.

The fragmentation of BI practices, perceived by the poor communication between the areas involved in the flow and by the difficulty in understanding the terms and information of the bases, is a factor that hinders the performance of the process, in agreement with Davenport (2006). The difficulty of unifying and centralizing the management of critical data as well as maintaining BI processes that guarantee the quality of information and the integration between the areas makes the practices fragment (DAVENPORT, 2006). Another evidenced factor is that the analysis is based on low quality, not validated or wrong information, which can cause delay and negatively affect the company's decisions and actions, as pointed out by Popovic et al. (2012), incurring waste and eventual failures in strategic decisions.

The philosophy and tools of the Lean Office allowed us to identify waste. Following the classification of Reno (2016), it can be said that the analyzed flow suffers mainly from border and knowledge waste. There are redundant tasks, for example, the SP area needs to make checks with the information from the database before using it, in order to be able to understand which concept is used in each field. Thus, there is the use of resources for a process that does not add value to the flow and can be eliminated and should already be delivered in previous steps without requiring revalidation.

There are quality problems in information and rework, commonly present in service processes according to Davenport (2006) and Popovic et al. (2012). In the current flow analyzed, it is noticed that there is a recurrence of reworks generated in more than one stage. Quality problems are reflected in the processing of the database when the consolidated information from the previous period is uncertain and when there is identification of problems in the database information only at the end of the analysis, that is, in one of the last stages of the value flow, carried out by the SP. This implies rework throughout the BI process and wasted resources. This problem is expected to be mitigated by inserting an information validation at the beginning of the process, and by improving communication between the areas.

There are also waiting problems, according to Ganesan and Gopalsamy (2019), when, for example, there is information in the database without correct coding or data without validation, making the end customers of the process wait. The wait includes that the process is redone and that the bases are ready to feed the analyzes, configuring waste by waiting. For 
Ganesan and Gopalsamy (2019), in BI processes, attention should be paid to wasted time in creating dashboards, difficulties in obtaining real and reliable data and delays in generating reports for the administration with the requested information. With the improvements proposed in the flow, through A3 studies, it is expected that errors will occur less frequently, reducing waiting situations.

\section{2 Analysis of the process under the Lean Office approach}

Regarding the application of Lean Office tools, it was possible to verify that VSM was crucial for the identification of process activities, time of operation and value flow. The tool also helped in the perception of waste, necessary improvements (kaizens) and in proposing a future state. The A3 tool, which includes others, such as the 5 Whys and 5W2Hs, was also effective for proposing and implementing improvements. The actions proposed in the A3 also included other Lean Office tools such as work standardization, poka-yoke applied to the execution of tasks without errors and performance indicators. Therefore, they were effective in allowing the visualization of the value flow and elimination of waste, in a process with natural difficulty in identifying value due to the flow of information and knowledge not being a physical flow of materials, in agreement with Almeida et al. (2017), Freitas et al. (2018) and Ganesan and Gopalsamy (2019).

According to Freitas et al. (2018), Monteiro et al. (2017), Rother and Shook (1999), Salunke and Hebbar (2015); Saurin et al. (2012), Sobek and Jimmerson (2016) and Tortorella et al., (2016), these would be the most effective tools for use in Lean production systems.

The steps adopted in the reported case of applying Lean Office were compatible with the steps for implementing Lean in administrative environments recommended by Tapping and Shuker (2010) and proved to be adequate for the purpose. The steps adopted allowed the identification of waste. The main types of waste identified were knowledge and border (such as: redundant tasks, quality problems and waiting) and are aligned with the waste in the office pointed out by Almeida et al. (2017), Gupta and Sharma (2018), Malladi et al. (2011) and Reno (2016).

When considering the Lean Office principles pointed out by Hicks (2007), it is observed that the case allowed the verification that it was possible to specify the value for the BI process, even though it is a process whose client is the company itself. Value is created when data analysis allows the generation of accurate information that will serve as a basis for 
decision making. In relation to the principle of value flow, the tools allowed the identification of activities that add or not add value in a service process (BI), as recommended by Ganesan and Gopalsamy (2019), with unnecessary or redundant ones (for example, checks in the Strategic Planning area) could be eliminated and others were created to allow greater fluidity to the process, avoiding rework and waiting for information errors. The minimization of quality problems in information also allows for an improvement in communication and, consequently, in the fluidity of the process (HICKS, 2007). The principle of pulled production was established since the beginning of the process only occurs when there is a request from Strategic Planning or from its customers. The last Lean principle, of seeking perfection, was initiated by the application of the Lean Office itself and by the involvement of the company's members in the steps taken, in accordance with the recommendations of Hicks (2007).

For Leite and Vieira (2015) Lean Office practices are relatively new in the service sector and in developing countries, with few documented approaches. The reported case contributes to the exemplification of this application in a specific service process.

\section{CONCLUSION}

The article brings two main scientific contributions, the detailed presentation of activities of a real BI process, which are little explored in the literature (involving activities of data capture and treatment; analysis and transformation of data into meaningful information and analysis of information for generate knowledge that underlies strategic decisions), which contributes to a better understanding and creation of a common vision about this process among researchers and practitioners; and a case study that highlights the effective contribution of applying the principles and tools of the Lean Office to identify waste, analyze causes and improve the performance and management of a BI process. The systematic bibliographic review conducted at the beginning of this research did not identify any publication on the application of Lean Office in this type of process. These contributions are useful both for theoretical knowledge in the area and for company managers.

Thus, based on what has been mapped, it is possible to affirm that the BI process has the macro stages of data collection, transformation into information, generation of knowledge and support for decision making. It was possible to identify the activities of these steps in greater depth, contributing to a better understanding of the activities of the BI process and its 
interfaces. This understanding contributes to the management and improvement of the process.

The analysis of the process was developed and the Lean Office tools used helped to deepen the understanding of the process, the identification of problems and the proposition of improvements. It was possible to identify in the VSM the stages that contained waste. Four main issues were identified to be addressed: 1 . Process not recurrently validated; 2 . Identification of inconsistencies in the database when generating the analyzes; 3 . Bases not easily traceable; 4. Failure to understand the base fields. Such questions were related to three main types of waste of knowledge and boundaries: redundant tasks, quality problems and waiting. The identification of these problems allowed the construction of $\mathrm{A} 3$, in order to identify the root cause and propose countermeasures.

The study revealed that the focus company, even with investments in infrastructure and BI tools and an initiative to establish a culture centered on data, as recommended by the literature in the area (DAVENPORT, 2006; OSZACK, 2016; WIXOM; WATSON, 2001), presents aspects of fragmentation of BI practices. As noted in the case, this is due, for example, to the difficulty of integrating the areas involved in the process and the correct definition of activities, which can generate waste of frontier and knowledge that cause inconsistencies in the format, definitions and standards of the data, resulting in multiple versions of indicators (data and information synthesized with meaning), bases with errors, rework and mistaken analyzes.

The study allowed the Lean Office to be applied in a financial services company, belonging to an environment of global competitiveness, but inserted in a context of developing economy. The principles and tools of the Lean Office proved to be suitable for this environment, given that they allowed the identification of improvements that enable better performance of the BI process. Another finding is that there was a good receptivity by the company's management, both in relation to the concepts and the culture of improvement proposed by Lean, two points presented by Gupta and Sharma (2018) as concerns for the implementation of the Lean Office in developing economies.

A limitation of the study was to analyze the information flow only in a BI process. For a more comprehensive investigation of $\mathrm{BI}$ processes, it is proposed, for future work, to analyze processes in other companies. Thus, it would be possible to create comparisons 
between them and possibly identify the most common problems for this type of flow, making it possible to generate contributions to theoretical knowledge in the area.

For future work, in addition to the steps taken in this case, it is proposed to cover and monitor the stage of implementation of the proposed improvements, in order to measure their impacts and compare with the initial situation, through the quality indicators proposed during the process analysis.

\section{References}

ALMEIDA, J. P. L.; GALINA, S.V.R.; GRANDE, M. M.; BRUM, D. G. Lean thinking: planning and implementation in the public sector. International Journal of Lean Six Sigma, v. 8, n. 4, p. 390-410, 2017.

ANTONY, J.; GUPTA, S.; SUNDER, V.; GIJO, E. V. Ten commandments of Lean Six Sigma: a practitioners' perspective. International Journal of Productivity and Performance Management, v. 67, n. 6, p. 1033-1044, 2018.

AZVINE, B.; CUI, Z.; NAUCK, D. Towards real-time Business Intelligence. BT Technology Journal, v. 23, n.3, p. 214-225, 2005.

BODEK, N. Prefácio. In: OHNO, Taiichi. Gestão dos postos de trabalho. Porto Alegre: Bookman, 2015.

BOLOGA, A.; BOLOGA, R. Business Intelligence using Software Agents. Database Systems Journal, v. 2, p. 31-42, 2011.

CAVAGLIERI, M.; JULIANI, J.P. Lean archives: o emprego do Lean Office na gestão de arquivos. Perspectivas em Ciência da Informação, v. 21, n. 4, p. 180-201, 2016.

CHEN, H.; CHIANG, R.H.L.; STOREY, V.C. Business intelligence and analytics: From big data to big impact. MIS Quarterly, v. 36, n. 4, 2012.

CHEN, J. C.; COX, R. A. Value Stream Management for Lean Office - A Case Study. American Journal of Industrial and Business Management, v. 2, p. 17-29, 2012.

DANESE, P.; MANFÈ, V.; ROMANO, P. A Systematic Literature Review on Recent Lean Research: State-of-the-art and Future Directions. International Journal of Management Reviews, v. 20, n. 2, p. 579-605, 2018.

DAVENPORT, T. H. Competing on Analytics. Harvard Business Review, January, p. 99$107,2006$. 
FREITAS, R.C.; FREITAS, M. C. D.; ODORCZYK, R. S. Lean Office contributions for organizational learning. Journal of Organizational Change Management, v. 31, n. 5, p. 1027-1039, 2018.

FREITAG, A. E. B.; SANTOS, J. C.; REIS, A. C. Lean Office and digital transformation: a case study in a services company. Brazilian Journal of Operations \& Production Management, v. 15, n. 4, p. 588-594, 2018.

GANESAN, S., GOPALSAMY, S., Business intelligence and advanced analytics: Impact and behavior of business decision making process. International Journal of Recent Technology and Engineering, v. 83, n. 3, p. 375-379, 2019.

GANGADHARAN, G. R.; SWAMI, S. N., Business Intelligence Systems: Design and Implementation Strategies. In: CONFERENCE ON INFORMATION TECHNOLOGY INTERFACES (ITI), 2004, Cavtat, Croácia.

GONZALES, R.; WAREHAM, J.; SERIDA, J. Measuring the Impact of Data Warehouse and Business Intelligence on Enterprise Performance in Peru: A Developing Country. Journal of Global Information Technology Management, v. 18, n. 3, p. 162-187, 2015.

GOTI, A.; DE LA CALE, A.; GIL, M. J. A.; ERRASTI, A.; BOM, P. R. D.; GARCIABRINGAS, P. Development and application of an assessment complement for production system audits based on data quality, IT infrastructure, and sustainability. Sustainability, v. 10, n. 12, p. 4679, 2018.

GUPTA, S.; SHARMA, M.. Empirical analysis of existing lean service frameworks in a developing economy. International Journal of Lean Six Sigma, v. 9, n. 4, p. 482-505, 2018.

HICKS, B. J. Lean information management: Understanding and eliminating waste. International Journal of Information Management, v. 27, p. 233-249, 2007.

HINES, P.; HOLWEG, M.; RICH, N. Learning to evolve: A review of contemporary lean thinking. International Journal of Operations \& Production Management, v. 24, n. 10, p. 994-1011, 2004.

KOENIGSAECKER, G. Liderando a transformação Lean nas empresas. Porto Alegre: Bookman, 2011.

LEITE, H. R.; VIEIRA, G.E. Lean philosophy and its applications in the service industry: a review of the current knowledge. Production, v. 25, n. 3, p. 529-541, 2015.

LOCHER, D. Lean office and service simplified: the definitive how-to guide. Boca Raton, FL: CRC Press, 2011.

LÖNNQVIST, A.; PIRTTIMÄKI, V. The Measurement of Business Intelligence. Information Systems Management, v. 23, n. 1, p. 32-40, 2006. 
MAVI, R. K.; STANDING, C. Cause and effect analysis of business intelligence (BI) benefits with fuzzy DEMATEL. Knowledge Management Research \& Practice, v. 16, n. 2, p. 245$257,2018$.

MAGALHÃES, J. C.; ALVES, A. C.; COSTA, N.; RODRIGUES, A. R. Improving processes in a postgraduate office of a university through lean office tools. International Journal for Quality Research, v. 13, n. 4, p. 797-810, 2019.

MALLADI, S.; DOMINIC, P. D. D.; KAMIL, A. Lean principles in IT services: a case study on implementation and best practices. International Journal of Business Information Systems, v. 8, n. 3, p. 247-268, 2011.

MCMANUS, H.L. Product development value stream analysis and mapping manual. Manual 1.0. Lean Aerospace Initiative. Massachusetts Institute of Technology, September, 116 p., 2005.

MONTEIRO, J. L. M. P; ALVES, A.C.; CARVALHO, M. S. F. B. S. Processes improvement applying Lean Office tools in a logistic department of a car multimedia components company. In: MANUFACTURING ENGINEERING SOCIETY INTERNATIONAL CONFERENCE, 2017, Vigo, Spain. Procedia... Manufacturing 13 (2017), p. 995-1002.

MUNTEAN, M. Business intelligence issues for sustainability projects. Sustainability, v. 10, n. 2, p. 335, 2018.

OLSZAK, C. M. Toward better understanding and use of business intelligence in organizations. Information Systems Management, v. 33, p. 105-123, 2016.

OLSZAK, C. M.; ZIEMBA, E. Business Intelligence as a key to management of an Enterprise. In: INFORMING SCIENCE AND IT EDUCATION (INSITE), 2003, Pori, Finlândia. Santa Rosa, CA: The Informing Science Institute.

PETRINI, M.; POZZEBON, M.; FREITAS, M. T. Qual é o Papel da Inteligência de Negócios (BI) nos Países em Desenvolvimento? Um Panorama das Empresas Brasileiras. In: ASSOCIAÇÃO NACIONAL DE PÓS-GRADUAÇÃO E PESQUISA EM ADMINISTRAÇÃO. 28o 2004. Anais... ENANPAD, Curitiba, PR, 2004.

POLYVYANYY, A.; OUYANG, C.; BARROS, A.; VAN DER AALST, W. M. P. Process querying: Enabling business intelligence through query-based process analytics. Decision Support Systems, v. 100, p. 41-56, 2017.

POPPENDIECK, M.; POPPENDIECK, T. Implementando o desenvolvimento Lean de software: Do conceito ao dinheiro. Porto Alegre: Bookman, 2011.

POPOVIC, A.; HACKNEY, R.; COELHO, P. S; JAKLIC, J. Toward business intelligence systems success: effects of maturity and culture on analytical decision making. Decision Support Systems, v. 54, n. 1, p. 729-739, 2012. 
RENO, G. W. S. Melhoria de produtividade na área de serviço de atendimento aos clientes de uma fabricante de bens de consumo através da aplicação da metodologia lean office. In: ENCONTRO NACIONAL DE ENGENHARIA DE PRODUÇÃO, 32, 2016. Anais...ENEGEP, p.1-1, 2016.

RICHARDS, G.; YEOH, W.; CHONG, A.Y. L.; POPOVIC, A. Business intelligence effectiveness and corporate performance management: an empirical analysis. Journal of Computer Information Systems, v. 59, n. 2, p. 188-196, 2019.

ROTHER, M.; SHOOK, J. Aprendendo a enxergar: mapeando o fluxo de valor para agregar valor e eliminar o desperdício. São Paulo: Lean Institute Brasil, 1999.

SAED, R. A. The Relationship between Business Intelligence and Business Success: An Investigation in Firms in Sharjah Emirate. American Journal of Business and Management, v. 2, p. 332-339, 2013.

SALUNKE, S. S.; HEBBAR, S. Value Stream Mapping: A continuous improvement tool for reduction in total lead time. International Journal of Current Engineering and Technology, v. 5, n. 2, p. 931-934, 2015.

SAURIN, T. A.; RIBEIRO, J. L. D.; VIDOR, G. A framework for assessing poka-yoke devices. Journal of Manufacturing Systems, v. 31, n. 3, p. 358-366, 2012.

SCHICK, A.; FROLICK, M.; ARIYACHANDRA, T. Competing with BI and analytics at Monster Worldwide. In: HAWAII INTERNATIONAL CONFERENCE ON SYSTEM SCIENCES, 44, 2011. Procedia... Kauai, HI, 2011.

SERAPHIM, E. C.; SILVA, I. B. DA; AGOSTINHO, O. L. Lean Office em organizações militares de saúde: estudo de caso do Posto Médico da Guarnição Militar de Campinas. Gestão \& Produção, v. 17, n. 2, p. 389-405, 2010.

SKYRIUS, R.; KAZAKEVIČIENÉ, G.; BUJAUSKAS, V. The Relationship between Management Decision Support and Business Intelligence: Developing Awareness. In: ROCHA, Á.; CORREIA, A. M.; WILSON, T., STROETMANN, K. A. Advances in Information Systems and Technologies. Springer, 2013, p. 587-598.

SOBEK, D.K.; JIMMERSON, C. Relatório A3: ferramenta para melhorias de processos. Lean Institute Brasil, 2016. Disponível em https://www.lean.org.br/artigos/90/relatorio-a3ferramenta-para-melhorias-de-processos.aspx . Acesso em 10 jan 2019.

SONG, W.; TAN, K.H.; BARANEK, A. Effective toolbox for lean service implementation. International Journal of Services and Standards, v. 5, n. 1, p. 1-16, 2008.

STEINMUELLER, W. ICTs and the possibilities for leapfrogging by developing countries. International Labour Review, v. 140, n. 2, p. 193-210, 2001. 
TAPPING, D.; SHUKER, T. Lean Office: Gerenciamento do fluxo de valor para áreas administrativas - 8 passos para planejar, mapear e sustentar melhorias Lean nas áreas administrativas. São Paulo: Leopardo Editora, 2010.

THOMPSON, W. J. J.; VAN DER WALT, J. S. Business intelligence in the cloud. South African Journal of Information Management, v. 2, n. 1, p. 1-5, 2010.

TORRES, R.; SIDOROVA, A.; JONES, M. C. Enabling firm performance through business intelligence and analytics: A dynamic capabilities perspective. Information \& Management, v. 55, n. 7, p. 822-839, 2018.

TORTORELlA, G. L., FOGLIATTO, F. S.; ANZANELlO, M.; MARODIN, G. A.; GARCIA, M.; ESTEVES, R. R. Making the value flow: application of value stream mapping in a Brazilian public healthcare organisation. Total Quality Management \& Business Excellence, v. 28, n. 13-14, p. 1544-1558, 2016.

VIDOR, G; SAURIN, T. A. Conceitos e características de sistemas poka-yokes: uma revisão da literatura. Revista Produção Online, v.11, n. 2, p. 344-368, 2011.

VUORI, V. Methods of defining business information needs. Frontiers of e-Business Research, October, p. 1-9, 2006.

WANG, H.; WANG, S. A knowledge management approach to data mining process for business intelligence. Industrial Management \& Data Systems, v. 108, n. 5, p. 622-634, 2008.

WILLIAMS, S.; WILLIAMS, N. The profit impact of Business Intelligence. São Francisco: Morgan Kaufmann, 2007.

WIXOM, B.; WATSON, H. An empirical investigation of the factors affecting data warehousing success. MIS Quarterly, v. 25, n. 1, p.17-41, 2001.

YIN, R. K. Estudo de Caso: Planejamento e Métodos. 2.ed. Porto Alegre: Bookman, 2001. 